\title{
A fruit to discover: Cucumis metuliferus E.Mey Ex Naudin(Kiwano)
}

\author{
Lydia Ferrara* \\ Department of Pharmacy, University of Naples Federico II, Via Domenico Montesano 49, 80131 Naples, Italy
}

\begin{abstract}
In recent years there has been a growing interest in natural bioactive substances following the affirmation of a medicine based on herbal remedies as an alternative to synthetic drugs whose purchase cost it is often excessive for many people. Furthermore, the analytical advanced techniques and pharmacological screening guarantee the safety of the extracts vegetables that more and more attract the consumer's attention prone to preserve your state of well-being with natural remedies. The kiwano satisfies various needs, as the fruit shows various properties: dietetic, pharmacological and nutraceutical.
\end{abstract}

\section{Introduction}

The Cucumis metuliferus (Kiwano) is the fruit of a climbing plant annual of the Cucurbitaceae family species used by humans a culinary purpose since the most remote times. The Kiwano originally from the south and Central Africa, is currently cultivated in the United States, Israel, Kenya and New Zealand for its characteristics fruits, which form the boundary ornamental for various dishes[1]. Kiwano is a herbaceous plant able to climb by means of cirrus opposite to the leaves; the male flowers they have five stamens welded together to each other half anthers, while the female flowers they own an entire ovary a more lodges. The fruit is oval, about $10 \mathrm{~cm}$ long, green when it is unripe, it takes on a colour orange yellow when it reached the ripeness, covered with strong spiny outgrowths, that the give a particular appearance; the flesh is soft emerald green, sprinkled with translucent white seeds. In this family are present in different percentages the cucurbitacines, toxic bitter triterpenoid substances [2], which in some edible varieties, have been reduced since improvement that man has made over time, reproducing only the plants more sweets. The fruits of the sweet varieties have been used to treat positive patients at HIV / AIDS [3] and in Nigeria the fruits and seeds of Cucumis metuliferus are eaten raw as supplements by populations of Africa [4,5], where the seeds can also be ground into fine flour, transformed into an emulsion with water, and then eaten to expel the parasites from the body [6].

Like all the plants of this family shows rapid growth, fears the cold, therefore it cannot be sow too early, but must wait late spring. During cultivation the plant needs a good supply of water, therefore in the case of one particularly dry season, we must intervene with frequent and abundant watering. The taste of the fruits is between the bananas and lemon; it and can be stored for some months at room temperature in dry place, without rotting.

\section{Analytical composition}

The analytical composition is very complex. In the pulp are present proteins, lipids, sugars, minerals including magnesium with high concentration, calcium, potassium, iron, phosphorus, zinc, copper; group B vitamins, vitamin A and vitamin $\mathrm{C}$ which concentration is four times higher than in lemon; high concentrations of carotene and á-tocopherol $[7,8]$.

Magnesium is an important mineral for the body's health: it is found in cells, tissues and organs. Its importance for health derives from the fact that it helps the muscle cells to relax, including those of the heart; it is essential for the process of mineralization and development of the skeletal system; favours the reduction of blood pressure, avoiding the onset of heart problems. Magnesium deficiency has been linked to heart disease, irregular heartbeat and palpitations, while people who eat many magnesium-rich foods also have a lower risk of stroke.

In the seeds there is an oil whose main components are linoleic acid and oleic acid, essential for carrying out the vital processes and to keep arterial pressure under control; palmitic acid, stearic, volatile esters of oleic acid which are responsible for the aroma [9]; cholesterol is absent; g.100 of fruit have a caloric power of $44 \mathrm{Kcal}[10]$. In the ethyl acetate extract of the fruit's exocarp have been identified flavonoids: rutin, miricetin and quercetin; in the methanol extract, the following terpenic compounds are identified: linalool and safrole [11]. Vitamin A, Vitamin $\mathrm{C}$ and other compounds with antioxidant properties slow down cellular aging. In particular, they are known to protect the integrity of the skin and to reduce the appearance of wrinkles and stains typical of old age.

\section{Pharmacological activity}

The fruit is highly sought after as a source of water from people of the Kalahari Desert [12], and is also a good source of energy with low caloric power, being rich in vitamin $\mathrm{C}$ and magnesium. In traditional South African medicine all parts of the plant are used: the fresh leaves are chewed, for their energetic and anti-fatigue effect, or they are eaten

${ }^{\star}$ Correspondence to: Lydia Ferrara, Department of Pharmacy, University of Naples Federico II, Via Domenico Montesano 49, 80131 Naples, Italy, E-mail: lyferrar@unina.it

Key words: kiwano, bio active substance, herbal remedies, synthetic drugs

Received: October 19, 2018; Accepted: October 29, 2018; Published: October 31,2018 
cooked, as is generally used for vegetables, or boiled for the preparation of herbal teas with a laxative action, or to prepare anti-inflammatory packs [13]. In the leaves, a saponin is contained which, foam when mixed with water: cucurbitacin $B$, a toxic substance of a triterpenic nature known to exhibit cytotoxic, anti-tumour and anti-inflammatory activities. The bitter compounds of the leaves can be neutralized when they are cooked; the peel is dried or cooked; the seeds are dried and ground into flour to prepare an effective potion against tapeworm [7].

Recent studies have shown that the fruit of Cucumis. metuliferus increases the values of blood parameters as haemoglobin, red blood cell counts and white blood cells, cell volume and in vitro shows antibacterial activity against Salmonella gallinarum [14]; shows antiviral activity, as demonstrated by the regression of symptoms in chickens, turkeys and other birds affected by avian pseudosepta due to the genus Avulavirus [15]; the extract of the pulp has a protective and anti-ulcer action on the mucous membranes of mice with a dose-dependent effect[16]; increases male fertility[17]; the glycosides extracted from the pulp possess antihyperglycemic dose-dependent activity in allosane-induced diabetes mellitus in rats $[18,19]$, the organic extracts of Kiwano leaves also present antimalarial activity with a suppression value of $98.55 \%$ compared to $100 \%$ of the chloroquine, suggesting the presence of active phytochemical compounds[20].

\section{Discussion and conclusion}

Kiwano is a fruit that meets various needs, as it shows numerous dietetic properties: the pulp besides being very rich in water has a high concentration of mineral salts, including potassium, while it is low in sodium; lipids and carbohydrates are present in low concentration, cholesterol is absent so it could be indicated in the diets of overweight subjects and in diabetics. The seeds contain a rich oil with a prevalence of unsaturated fatty acids, compared to saturated ones, which provide health benefits for the control of blood pressure, preventing cardiovascular diseases. The oil is rich in antioxidant substances such as carotenoids and tocopherols that bring many benefits to cells and organs by neutralizing the damage of free radicals that cause cardiovascular and cancer diseases, also strengthening the immune system. From our research it is clear that even the peel has pharmacological properties, therefore dried and pulverized can be used for dietary purposes for the presence of antioxidant substances and anti-free radicals. In fact, rutin, miricetin and quercetin are polyphenolic compounds belonging to the chemical category of flavonoids: the rutin which is present in greater concentration makes hyaluronic acid more readily available, strengthens the properties of vitamin $\mathrm{C}$, is a platelet antiplatelet, an antioxidant, with anti-inflammatory, spasmolytic, antiviral activity.

Only the bitter fruits of C. metuliferus are toxic due to the presence of cucurbitans triterpenic substances that act negatively on the liver and kidneys for an increase in uricemia, aspartate aminotransferase enzymes, alanine aminotransferase, alkaline phosphatase and total proteins. The sweet varieties, on the other hand, due to the remarkable ease of expansion of this plant, could represent an economically advantageous nutritional source to alleviate malnutrition with the consumption of the fruit as it is or provide active phytochemicals to the pharmaceutical industries for the preparation of supplements.

\section{References}

1. Morton JF (1987) The horned cucumber alias "Kiwano" (Cucumis metuliferus, cucurbitaceae). Econ Bot 41: 325-326.

2. Teuscher E, Lindequist U (1994) Triterpene. In: Biogene Gifte-Biologie,chemie, pharmakologie; 2. Auflage. Gustav fischer verlag, Stuttgart, Jena, New York, 159- 175.
3. Wannang NN, Jimam NS, Omale S, Dapar MLP, Gyang SS, et al. (2007) Effects of Cucumis metuliferus (Cucurbitaceae) fruits on enzymes and haematological parameters in albino rats. Afr J Biotechnol 6: 2515-2518.

4. Bruecher H (1977) Cucurbitaceae. In: Tropische Nutzpflanzen. Springer verlag, Berlin. 258-297.

5. Keith ME, Renew A (1975) Notes on some edible plants found in the Kalahari. Gemsbok Park. Koedoe 18: 1-12.

6. Chiej R (1984) Encyclopaedia of Medicinal Plants. MacDonald.

7. Usman JG, Sodipo OA, Kwaghe AV, Sandabe UK (2015) Uses of Cucumis metuliferus: A Review. Cancer Biol 5: 24-34.

8. Hussein AHA (2009) Impact of sewage sludge as Organic manure on soil properties, growth, yield and nutrient contents of cucumber crop. J Ppl Sci 9: 1401-1411.

9. Bódalo A, Bastida J, Máximo MF, Hidalgo AM, Murcia MD (2005) Production of (E) 10- hydroxy-8-octadecenoic acid with lyophilized microbial cells. Am J Biochem Biotechnol 1: 1- 4 .

10. Romero RMA, Vazquez OML, Lopez HJ, Simal LJ (1992) Physical and analytical characteristics of the kiwano. J Food Comp Anal 5: 319-322.

11. Ferrara L (2006) The dietary importance of a tropical fruit: the Kiwano. Ingredienti Alimentari 6: 14-17.

12. VanWyk BE, Gercke N (2000) People's plants: a guide to useful plants of Southern Africa. Briza.

13. Bester SP, Condy G (2013) Cucumis metuliferus E.Mey. ex Naudin. Flow plan Afr 63: 56-64.

14. Usman JG, Sodipo OA, Sandabe UK (2014) In vitro antimicrobial activity of Cucumis metuliferus E. Mey. Ex. Naudin fruit extracts against Salmonella gallinarum. Internat J Phytomed 6: 268-274.

15. Wannang NN, Kwanashie HO, Ede SO (2010) Antiviral activity of the fruit extract of Cucumis metuliferus E. Meye (Curcubitaceae) in chicks. Afr J Basic Appl Sci 2: 89-93.

16. Wannang NN, Gyang SS, Omale S, Maxwell LP, Gyang SS, et al. (2009) The effect of Cucumis metuliferus E. Meye (Cucurbitaceae) on rat gastric functions and mucosal integrity. J Nat Prod Med 12: 37-39

17. Wannang NN, Jiman NS, Gyang SS, Bukar BB, Gotom S (2008) Effects of Cucumis metuliferus E. Mey. ex. Naud. (Cucurbitaceae) fruit extract on some male reproductive parameters in adult rats. Afr J Phar Pharmacol 2:48-51.

18. Jimam N, Wannang N, Omale S, Gotom B (2010) Evaluation of the hypoglycemic activity of Cucumis metuliferus (Cucurbitaceae) fruit pulp extract in normoglycemic and alloxan-induced hyperglycemic rats. J Young 2: 384-387. [Crossref]

19. Gotep J (2011) Glicosides fraction extracted from fruit pulp of Cucumis metuliferus E. Meyer has anti-hyperglycemic effect in rats with induced diabetes. J Nat Pharm 13: 450-487.

20. Mzena T, Swai H, Chacha M (2018) Antimalarian activity of Cucumis metuliferus and Lippia kituiensis against plasmodium berghei infection in mice. Res Per Trop Med 9:81-88. [Crossref]

Copyright: (C2018 Ferrara L. This is an open-access article distributed under the terms of the Creative Commons Attribution License, which permits unrestricted use, distribution, and reproduction in any medium, provided the original author and source are credited. 